ISSN 0130-8521. Передгірне та гірське землеробство і тваринництво. 2021. Вип. 70 (2)

DOI: $10.32636 / 01308521.2021-(70)-2-4$

UDC 633.844:631.526.3

O. M. SLUCHAK, scientist

O. P. VOLOSHCHUK, I. S. VOLOSHCHUK, doctors of agricultural sciences

V. V. HLYVA, candidate of agricultural sciences

M. Yu. VOLOSHCHUK, scientist

Institute of Agriculture of Carpathian Region of NAAS

Hrushevskoho street, 5, v. Obroshyne, Lviv district, Lviv region,

81115, e-mail: olexandravoloschuk53@gmail.com

\title{
CURRENT STATE OF WHITE MUSTARD PRODUCTION AND ITS NATIONAL VALUE
}

The article substantiates the prospects for growing white mustard as an important financial source of agricultural enterprise. The sowing areas in the world, in Ukraine and markets for the products are given. A comprehensive analysis of economically valuable properties of the culture and its application as a food and technical culture has been made. Mustard is a valuable crop precursor: liberates the field early; a powerful root system drains the soil well, enriches it with organic matter; root and crop residues have a depressing effect on the development of diseases. The root system is able to assimilate nutrients from poorly soluble forms of potassium and phosphorus, therefore it can grow on low-fertile soils with a slightly acidic reaction. Mustard is an ecologically plastic crop. The formation of 1 ton of seeds requires $55-60 \mathrm{~kg}$ of nitrogen, $25-30 \mathrm{~kg}$ phosphorus and $25-35 \mathrm{~kg}$ potassium. The agro-ecological advantages of growing mustard in Ukraine, its medicobiological properties, high profitability of production (more than $110 \%$ ) contribute to the further development of the sales market, its processing and increase the profitability of the crop.

Mustard is a cheap and effective fertilizer, green manure. Seeds (almost $100 \%$ of use) can be used in many areas of production. A by-product is mustard meal, which, after degreasing and grinding, turns into mustard powder - a product that is appreciated in the domestic and foreign markets. Mustard oil is used in food, confectionery, canning, margarine, soap-making, perfumery, paint and varnish industries. Natural antiseptic properties, due to the specific chemical composition and the presence of essential oil, make it possible to use it in medicine. Mustard oil is distinguished by a high content of biologically active substances necessary for our body (vitamins (A, D, E, K), fatty acids, phytosterols, chlorophyll, phytoncides etc.). Linoleic and linolenic essential fatty acids in mustard oil improve functioning of the cardiovascular system, normalize fat metabolism, maintain optimal hormonal balance, help strengthen immune system, and neutralize harmful effects of toxins.

(C) Sluchak O. M., Voloshchuk O. P., Voloshchuk I. S., Hlyva V. V., Voloshchuk M. Yu., 2021 
It was determined that a number of scientific institutions of the National Academy of Agrarian Sciences of Ukraine system are working on the development, testing and transfer to production of new varieties of mustard.

The main reasons for the insufficient popularity of the culture are given, they do not contribute to its spread into production - absence of new ecologically plastic varieties and imperfect cultivation technologies related to other oilseeds.

Key words: white mustard, variety, sowing areas, sales markets, meaning.

\section{Случак О. М., Волощук О. П., Волощук І. С., Глива В. В., Волощук М. Ю. \\ Інститут сільського господарства Карпатського регіону НААН \\ Сучасний стан виробництва гірчиці білої та її народногосподарське значення}

Обгрунтовано перспективи вирощування гірчиці білої як важливого фінансового джерела сільськогосподарського підприємства. Наведено площі посівів у світі й Україні та ринки збуту продукції. Зроблено всебічний аналіз їі господарсько цінних властивостей й застосування як продовольчої і технічної культури. Гірчиця - цінний попередник для культур: рано звільняє поле; потужна коренева система добре дренажує грунт, збагачує органічними речовинами; кореневі та пожнивні рештки гнітюче впливають на розвиток хвороб. Коренева система має здатність засвоювати поживні речовини 3 важкорозчинних форм калію та фосфору, тому може рости на низькородючих грунтах із слабокислою реакцією. Гірчиця $\epsilon$ екологічно пластичною культурою. На формування 1 т насіння потребує 55-60 кг азоту, 25-30 фосфору та 25-35 кг - калію. Агроекологічні переваги вирощування гірчиці в Україні, іiі медико-біологічні властивості, висока рентабельність виробництва продукції (понад 110 \%) сприяють подальшому розвитку ринку збуту, іï переробки та підвищення прибутковості культури.

Гірчиця $\epsilon$ дешевим i ефективним засобом удобрення грунту як сидеральна культура. Насіння (майже $100 \%$ використання) можна застосовувати в багатьох галузях виробництва. Побічний продукт - гірчичний шрот, який після знежирення та подрібнення перетворюється на гірчичний порошок - продукт, що ціниться на вітчизняному та зовнішньому ринках. Олію гірчиці використовують у харчовій, кондитерській, консервній, маргариновій, миловарній, парфумерній та лакофарбовій промисловості. Природні антисептичні властивості, зумовлені специфічним хімічним складом та наявністю ефірної олії, дозволяють застосовувати ії і в медицині. Гірчичну олію вирізняє високий вміст біологічно активних речовин, потрібних нашому організмові (вітаміни (A, D, E, K), жирні кислоти, фітостероли, хлорофіл, фітонциди тощо). Лінолева та ліноленова незамінні жирні кислоти, що містить олія гірчиці, поліпшують роботу серцево-судинної системи, нормалізують жировий обмін, підтримують оптимальний гормональний баланс, сприяють зміцненню імунітету, нейтралізують шкідливий вплив токсинів. 
Визначено, що наукові установи системи Національної академії аграрних наук України ведуть роботу із розробки, випробування та передачі в виробництво нових сортів гірчиці.

Наведено основні причини недостатньої популярності культури, що не сприяють іiі поширенню в виробництві, а це відсутність нових екологічно пластичних сортів та недосконалі технології вирощування, споріднені 3 іншими олійними культурами. значення.

Ключові слова: гірчиця біла, сорт, площі посівів, ринки збуту,

A feature of modern world agribusiness is the progressive growth of energy crops production, especially oilseeds. According to analysts, in the coming years the demand for these crops will only increase, as they are a reliable financial source, the main market for products is Western Europe and New World [29].

World sown areas under mustard in recent years range from 0.7 to 1.1 million hectares. The main player in the world market of food mustard is Canada - up to $70 \%$ of export-import operations. EU countries import up to 100,000 tons of mustard seeds annually and European purchase prices are much higher than in Ukraine, which in the long run should be taken into account by Ukrainian farmers. Mustard of the highest quality that meets the developed standards is classified as food, and unfit for human consumption - to technical. Accordingly, Canada and the United States produce highquality mustard, the Black Sea countries (Ukraine, Russia) - ordinary industrial. And the countries of the Indian continent (India, Nepal) are engaged in the cultivation of both conventional for food and technical [25, 29].

In Ukraine, sunflower is mostly produced among oilseeds, and white mustard could be an alternative crop, which makes it possible to increase the production of vegetable oils without deteriorating the condition of the soil. In search of high-yielding essential oil crops, scientists and businesses are increasingly paying attention to mustard, in addition, the dynamics of the market for this crop shows an increase in demand for it in recent years. In terms of crop area, this crop is among the top ten world leaders, and in Ukraine its area is second only to sunflower, rapeseed, soybean and flax oilseeds. Agri-environmental benefits of mustard cultivation in Ukraine, its medical and biological properties, high profitability of production (over $110 \%$ ) contribute to the further development of the market for mustard, its processing and increase the profitability of the crop. Its total area as a "niche culture" is in the range of 49.5-59.0 thousand hectares. It is a reliable 
financial source that successfully competes with sunflower and soybeans, while up to $90 \%$ of all seeds grown in Ukraine are exported (about 40 thousand tons) [26].

Mustard seed production in Ukraine is a chaotic phenomenon rather than purposeful. The reasons for such fluctuations in the popularity of culture should be considered in two contexts: first, in agrobiological (lack of production of varieties with a sufficient level of adaptive traits to the complex of abiotic and biotic adverse environmental factors); secondly - in agro-technological (the vast majority of agricultural producers use outdated cultivation technologies at best, at worst - use some technological methods of zonal technologies for growing related crops, especially rapeseed). According to analysts, for the first time in the last few seasons there is a slight increase in the gross harvest of mustard seeds, which contributed to the expansion of sown areas. Thus, in 2018 the area under mustard increased by 17.4 thousand hectares compared to the previous one and amounted 57.9 thousand hectares. Most mustard is grown in the southern regions of Ukraine, about $26 \%$ of its crops are, in particular, in the Kherson region (15 thousand hectares). Also, a significant part of mustard sown areas is concentrated in Zaporizhia (8.7 thousand hectares) and Luhansk (8 thousand hectares) regions. The average yield of mustard is much higher than in the rest of the world: blue mustard (Sarepta) from 1.0 to $1.2 \mathrm{t} / \mathrm{ha}$, white - from 1.5 to $2.5 \mathrm{t} / \mathrm{ha}$ of seeds and up to $30 \mathrm{t} / \mathrm{ha}$ - green mass $[9,17]$.

The rapid dynamics of climate change in the direction of warming also contributes to the expansion of white mustard crops, which significantly changes the usual ideas about the diversity of biological set and technological capabilities of long-known crops [5, 13].

Mustard is an ecologically plastic crop among oil cultures [14, 28]. It is undemanding to environmental conditions, grows on almost all types of soil but requires the presence of nutrients in the soil. It consumes $55-60 \mathrm{~kg}$ of nitrogen, $25-30 \mathrm{~kg}$ of phosphorus and $25-35 \mathrm{~kg}$ of potassium to form 1 ton of seeds. It is recommended to apply phosphorus-potassium fertilizers under the main tillage. The optimal is early sowing period, simultaneously with the early cereals. Sow in a continuous row method. And early sowing has the following benefits:

a) low positive temperatures and moist topsoil contribute to the formation of a strong root system and leaf rosette, which increases the competitiveness of the crop against weeds; 
b) mustard is a long-day plant, so in the case of late sowing, it is faster to go through all phases of growth and development, which negatively affects yields;

c) early sowing helps to reduce the harmfulness of cruciferous fleas.

Productive consumption of soil moisture makes the crop more drought resistant. White mustard gives high yields of green mass, which is well eaten by animals, so it has long been used for green fodder. It is also a honey crop $[2,23]$.

White mustard is undemanding to environmental conditions, grows on almost all types of soils, except light sandy (undesirable). The root system is able to absorb nutrients from sparingly soluble forms of potassium and phosphorus, so it can grow on low-fertile soils with a weak acid reaction. The culture is cold-resistant, the seeds germinate at a temperature of $+1 \ldots+3{ }^{\circ} \mathrm{C}$, seedlings in the rosette phase can withstand short-term spring frosts to $-7 \ldots-9{ }^{\circ} \mathrm{C}$. Optimal moisture supply $-350-450 \mathrm{~mm}$ during the growing season. Due to the early sowing of mustard, it makes the most efficient use of autumn-winter moisture reserves [18, 24].

An excellent green manure that can improve the condition of the soil, its fertility is an invaluable reserve for the use of white mustard on green manure. $90 \%$ of its root system penetrates deeper into the arable layer and well drains the soil layers, increases its permeability, aeration, suppresses diseases and pathogens which are contained in the soil. Mustard root secretions contain organic acids that, when interacting with the soil, are able to convert a number of mineral nutrients into accessible forms for the next crop. It is believed that the result after sowing mustard on green manure is similar to the introduction of humus. This culture structures the soil, enriches it with both organic and mineral nutrients due to the ability of the root system to dissolve and absorb nutrients inaccessible to other plants. Mustard reduces the population of pests and fungal infections in the soil. As a green manure - a good way to increase soil fertility and quality, which saves on fertilizers and plant protection products. It is a plantphytomeliorant, because its root and crop residues inhibit the development of many diseases, the causative agents of which live in the soil. The use of mustard greens makes it possible to compensate significant proportion of biological forms and mineral phosphorus-potassium fertilizers [4, 15].

According to A. Gusarova, mustard leaves about $10 \mathrm{t} / \mathrm{ha}$ of crop residues in the air-dry mass, which, if properly involved in the soilabsorbing complex, can improve the presence of organic matter in the soil $[6,10,16]$. During decomposition, mustard fills the soil with all the 
necessary elements, in particular: 11-12 g of nitrogen compounds, $12-15 \mathrm{~g}$ of potassium and up to $1.9 \mathrm{~g}$ of phosphorus per square meter. All elements are in a form easily accessible to plants.

Mustard is a promising crop (it can yield almost as good as spring rape), because plant biology allows it to be used not only as a good precursor that can improve agrophysical and phytosanitary properties of the soil, but also a cheap and effective means of fertilizing the soil as green manure crops, among which mustard is one of the most effective. Seeds can be used in many industries, and the processing of crop residues is also a great benefit, which allows to obtain fuel briquettes and pellets [20]. It is inexpedient to consider the culture of mustard as a raw material for oil production, because today there are technologies of almost $100 \%$ use not only of seeds, products of its primary processing, but also non-grain part of the crop. By-product - mustard meal, which after degreasing and grinding turns into mustard powder - a product that is valued in domestic and foreign markets on a par with oil. It is a major component of table mustard and mayonnaise, a variety of sauces and condiments, marinades and canning mixes. Mustard oil is used in the food, confectionery, canning, margarine, soap, perfume and paint industries. Natural antiseptic properties, due to the specific chemical composition and the presence of essential oil, allow it to be used in medicine [7, 8].

Mustard oil is characterized by a high content of biologically active substances needed by our body (vitamins (A, D, E, K), fatty acids, phytosterols, chlorophyll, volatile acids etc.). Linoleic and linolenic essential fatty acids in oil mustard, improves the cardiovascular system, normalizes fat metabolism, maintains optimal hormonal balance, strengthens the immune system, neutralizes the harmful effects of toxins. Antioxidant vitamin A normalizes metabolism, improves vision, protects skin and mucous membranes from healing, increased level of fat-soluble vitamin $\mathrm{E}$ in mustard oil is necessary for proper absorption of vitamins of other groups, normalization of metabolic processes, maintenance of energy balance, it prevents premature aging and destruction of body cells.

This powerful antioxidant has immune-stimulating, antiinflammatory, wound healing and rejuvenating properties; helps lower cholesterol, prevents blood clots, strengthens the walls of blood vessels and capillaries. When applied topically, mustard oil is recommended in the treatment of arthritis, polyarthritis, rheumatism, radiculitis. It well relieves tension in muscles and ligaments after strenuous exercise. In folk medicine it is used for faster healing of cuts and injuries [3, 19]. 
It is also necessary to mention the constant demand for mustard seeds from the food and confectionery industries. In particular, its seeds are used to make high-grade bread (mustard bread), and the addition of mustard oil to the dough allows you to double the shelf life of bread before hardening, compared to traditional recipes. In the canning industry, mustard is used to make the best varieties of canned fish and meat, successfully replacing Provencal oil - it is believed that the "brand" secret of the popular "Riga sprats" is in the use of mustard oil. Mustard oil is used in the food, confectionery, canning, margarine, soap, perfume and paint industries. Natural antiseptic properties, due to the specific chemical composition and the presence of essential oil, allow it to be used in medicine $[1,12]$.

Mustard seed production in Ukraine is a chaotic phenomenon rather than purposeful. The reasons for such fluctuations in the popularity of culture should be considered in two contexts: first - in agrobiological (lack of production of varieties with a sufficient level of adaptive traits to the complex of abiotic and biotic adverse environmental factors); secondly - in agro-technological (the vast majority of agricultural producers use outdated cultivation technologies, at worst - use some technological methods of zonal technologies for growing related crops, especially rapeseed) [11, 21, 22, 27, 30-32].

Today, a number of scientific institutions of the National Academy of Agrarian Sciences of Ukraine are working on the development, testing and production of new mustard varieties. In particular: Institute of Oilseeds NAAS (Zaporizhia region), Prykarpattia State Agricultural Research Station of the Institute of Agriculture of the Carpathian region NAAS, Prykarpattia National University n-d after Vasyl Stefanyk (Ivano-Frankivsk region), National Botanical Garden n-d after M. M. Hryshko of the National Academy of Sciences of Ukraine (Kyiv), Khmelnytsky State Agricultural Research Station of the Institute of Feed and Agriculture of Podillya NAAS, LLC "NDVAP "Ukrainian Mustard" (Khmelnytsky region), National Research Center "Institute of Agriculture NAAS" (Chabany), Institute of Agriculture of Western Polissia of NAAS (Rivne region) and others. For sowing it is necessary to use varieties adapted to the growing conditions in the relevant soil and climatic zones, which have passed the State variety test.

According to analysts, for the first time in the last few seasons there is a slight increase in the gross harvest of mustard seeds, which contributed to the expansion of sown areas. Thus, in 2018 the area under mustard in Ukraine increased by 17.4 thousand hectares compared to the previous one 
and amounted to 57.9 thousand hectares. Most mustard is grown in the southern regions of Ukraine, about $26 \%$ of its crops are, in particular, Kherson region (15 thousand hectares), Zaporizhzhia (8.7 thousand hectares) and Lugansk (8 thousand hectares) region [5].

Conclusions. The conditions of the Western Forest-Steppe zone meet the biological requirements of the culture in terms of natural soil fertility, the sum of effective temperatures and the amount of precipitation.

The reasons for the limited spread of white mustard in production are the insufficient number of new ecological and plastic varieties, limited production of pre-seasonal seeds and imperfect technology of its cultivation.

\section{Список використаної літератури}

1. Базалій В. В., Жуйков О. Г. Еколого-технологічне обгрунтування способу основного обробітку грунту при вирощуванні гірчиці білої в зоні Сухого Степу. Таврійський науковий вісник. 2012. Вип. 80. С. 9-14.

2. Велкова Н. И., Наумкин В. П. Использование горчицы белой и продуктов ее переработки в питании, медицине и косметике. Орел : ОрелГАУ, 2014. $154 \mathrm{c}$.

3. Видові особливості формування зеленої маси гірчиці в умовах Лівобережного Лісостепу України / А. В. Мельник та ін. Вісник Харківського національного аграрного університету. 2017. № 2. C. 79-83.

4. Власенко Н. Г., Коротких Н. А. Влияние агротехнических приемов на фитосанитарные свойства полевых капустных культур в отношении сорняков. Агрохимия. 2002. № 10. С. 58-63.

5. Гірчиця біла та іiі ефективне використання в біологізації землеробства / І. А. Шувар та ін. Львів, 2009. 69 с.

6. Гірчиця / В. О. Мазур та ін. ІваноФранківськ : Симфонія форте, 2009. 88 с.

7. Гірчична олія - користь для організму і шкода, склад і як приймати для лікування.

URL: http://radka.in.ua/zdorovya/girchichne-maslokorist-dlia-organiz.html (дата звернення: 03.09.2021).

8. Гірчичне масло: склад, користь,

\section{References}

1. Bazalii V. V., Zhuikov O. H. Ecological and technological substantiation of the method of basic tillage when growing white mustard in the Dry Steppe zone. Tavriiskyi naukovyi visnyk. 2012. Issue 80. P. 9-14.

2. Velkova N. I., Naumkin V. P. The use of white mustard and products of its processing in food, medicine and cosmetics. Orel : OrelGAU, 2014. 154 p.

3. Specific features of the formation of the green mass of mustard in the conditions of the Left-Bank Forest-Steppe of Ukraine / A. V. Melnyk et al. Visnyk Kharkivskoho natsionalnoho ahrarnoho universytetu. 2017. No. 2. P. 79-83.

4. Vlasenko N. G., Korotkih N. A. The influence of agricultural practices on the phytosanitary properties of field cabbage crops in relation to weeds. Agrohimiia. 2002. No. 10. P. 58-63.

5. White mustard and its effective use in the biologization of agriculture / I. A. Shuvar et al. Lviv, 2009. 69 p.

6. Mustard / V. O. Mazur et al. IvanoFrankivsk : Symfoniia forte, 2009. 88 p.

7. Mustard oil - benefits for the body and harm, composition and how to take for treatment.

URL: http://radka.in.ua/zdorovya/girchichne-maslokorist-dlia-organiz.html (last accessed: 03.09.2021).

8. Mustard oil: composition, benefits, properties, treatment and contraindications. 
властивості, лікування і протипоказання. Застосування гірчичного масла в косметології для обличчя та волосся. URL: http://inmoment.com.ua/beauty/beautifulbody/mustard-oil.html (дата звернення: 03.09.2021).

9. Губенко Л. Гірчичні реалії та перспективи. Пропозиція. 2019. № 1. URL: https://propozitsiya.com/ua/girchychni-

realiyi-ta-perspektyvy (дата звернення: 02.09.2021).

10. Гусарова А. Гірчиця як попередник пригнічує поширення кореневих гнилей. URL: https://superagronom.com/news/6406girchitsya-yak-poperednik-prignichuyeposhirennya-korenevih-gniley-doslidjennya (дата звернення: 07.09.2021).

11. Жуйков А. Г. Влияние орошения на количественно-качественные показатели урожая семян горчицы разных видов. Сборник научныл трудов Курганской СХА. 2014. Вып. 3. С. 27-29.

12. Жуйков А. Г. Эффективность инкрустирования семян и внекорневых подкормок при выращивании горчицы в неорошаемых условиях Юга Украины. Сборник научных трудов Курганской СХА. 2014. Вып. 4. С. 16-19.

13. Жуйков Г. Є., Жуйков О. Г. Роль гірчиці та продуктів іiі переробки у формуванні продуктового сегменту АПК України. Бізнес-навігатор : наукововиробничий журнал. 2013. Вип. 1 (30). C. 141-147.

14. Жуйков О. Г. Гірчиця в Південному степу: агроекологічні аспекти i технології вирощування. Херсон : Грінь Д. С., 2014. 416 с.

15. Жуйков О. Г., Жуйков Г. Є. Економіко-енергетична ефективність виробництва насіння гірчиці в зоні Південного Степу. Бізнес-навігатор. 2014. № 3. C. 188-194.

16. Жуйков О. Г. Комплексна агробіологічна оцінка сучасного сортового складу гірчиці білої в умовах Сухого Степу. Зроиуване землеробство. 2012. Вип. 58. С. 94-99.
The use of mustard oil in cosmetology for face and hair. URL: http://inmoment.com.ua/beauty/beautifulbody/mustard-oil.html (last accessed: 03.09.2021).

9. Hubenko L. Mustard realities and prospects. Propozytsiia. 2019. No. 1. URL: https://propozitsiya.com/ua/girchychnirealiyi-ta-perspektyvy (last accessed: 02.09.2021).

10. Husarova A. Mustard as a precursor inhibits the spread of root rot. URL: https://superagronom.com/news/6406girchitsya-yak-poperednik-prignichuyeposhirennya-korenevih-gniley-doslidjennya (last accessed: 07.09.2021).

11. Zhujkov A. G. Influence of irrigation on the quantitative and qualitative indicators of the yield of mustard seeds of different types. Sbornik nauchnyh trudov Kurganskoj SHA. 2014. Issue 3. P. 27-29.

12. Zhujkov A. G. Efficiency of seed encrustation and foliar dressing when growing mustard in non-irrigated conditions in the South of Ukraine. Sbornik nauchnyh trudov Kurganskoj SHA. 2014. Issue 4. P. 1619.

13. Zhuikov H. Ye., Zhuikov O. H. The role of mustard and its processed products in the formation of the product segment of the agro-industrial complex of Ukraine. Biznesnavihator : naukovo-vyrobnychyi zhurnal. 2013. Issue 1 (30). P. 141-147.

14. Zhuikov O. H. Mustard in the Southern steppe: agroecological aspects and cultivation technologies. Kherson : Hrin D. S., 2014. 416 p.

15. Zhuikov O. H., Zhuikov H. Ye. Economic and energy efficiency of mustard seed production in the southern steppe zone. Biznes-navihator. 2014. No. 3. P. 188-194.

16. Zhuikov O. H. Comprehensive agrobiological assessment of the modern varietal composition of white mustard in dry steppe conditions. Zroshuvane zemlerobstvo. 2012. Issue 58. P. 94-99.

17. Zhuikov O. H. Mustard market in Ukraine: state, problems, prospects. Tavriiskyi naukovyi visnyk. 2014. No. 87. P. 
17. Жуйков О. Г. Ринок гірчиці в Україні: стан, проблеми, перспективи. Таврійський науковий вісник. 2014. № 87. C. $39-48$.

18. Козіна Т. В. Удосконалення окремих елементів сортової технології вирощування гірчиці білої в умовах Лісостепу Західного : автореф. дис. на здобуття наук. ступеня канд. с.-Г. наук : 06.01.09 «Рослинництво». Кам'янецьПодільський, 2013. 20 с.

19. Льон олійний, гірчиця. Стратегія виробництва олійної сировини в Україні (малопоширені культури) / І. А. Шевченко та ін. ; Інститут олійних культур НААН України. Запоріжжя : СТАТУС, 2017. 44 с.

20. Ляпін Г. Нова «професія» гірчиць. Хлібороб України. 1988. № 6. С. 22.

21. Мастеров А. С., Караульный Д. В., Плевко Е. А. Урожайность и качество семян горчицы белой в зависимости от применения микроудобрений и регуляторов роста. Вестник Белорусской государственной сельскохозяйственной академии. 2014. № 3. С. 64-68.

22. Мельник А. В. Жердецька С. В. Вплив доз мінеральних добрив на врожайність гірчиці ярої сизої в умовах Північно-Східного Лісостепу України. Науковий вісник Начіонального університету біоресурсів $i$ природокористування Украӥни. 2017. № 269. C. 177-185.

23. Мельник Т. І., Алі Ш., Колосок В. Г. Якість насіння гірчиці білої залежно від сорту та норм висіву в умовах ПівнічноСхідного Лісостепу України. Таврійський науковий вісник. 2020. № 113. С. 92-97.

24. Сидерати в сучасному землеробстві / I. А. Шувар та ін. ІваноФранківськ : Симфонія форте, 2015. 156 с.

25. Слісарчук М. Вирощування гірчиці білої як олійної культури. Агробізнес Сьогодні. URL: http://agrobusiness.com.ua/agro/ahronomiiasohodni/item/10623-vyroshchuvanniahirchytsi-biloi-iak-oliinoi-kultury.html (дата звернення: 30.08.2021).

26. Состояние и перспективы
39-48.

18. Kozina T. V. Improvement of individual elements of varietal technology for growing white mustard in the conditions of the Western forest-steppe : avtoref. of dis. for degree of Cand. of agric. sci. : spec. 06.01.09 "Plant sciences". Kamianets-Podilskyi, 2013. $20 \mathrm{p}$.

19. Oil flax, mustard. Strategy for the production of oilseeds in Ukraine (rare crops) / I. A. Shevchenko et al. ; Instytut oliinykh kultur NAAN Ukrainy. Zaporizhzhia : STATUS, 2017. 44 p.

20. Liapin H. The new "profession" mustards. Khliborob Ukrainy. 1988. No. 6. P. 22.

21. Masterov A. S., Karaul'nyj D. V., Plevko E. A. Productivity and quality of white mustard seeds, depending on the use of micronutrient fertilizers and growth regulators. Vestnik Belorusskoj gosudarstvennoj sel'skohoziajstvennoi akademii. 2014. No. 3. P. 64-68.

22. Melnyk A. V., Zherdetska S. V. Influence of doses of mineral fertilizers on the yield of gray spring mustard in the northeastern forest-steppe of Ukraine. Naukovyi visnyk Natsionalnoho universytetu bioresursiv i pryrodokorystuvannia Ukrainy. 2017. No. 269. P. 177-185.

23. Melnyk T. I., Ali Sh., Kolosok V. H. The quality of white mustard seeds, depending on the variety and seeding rates in the northeastern Forest-steppe of Ukraine. Tavriiskyi naukovyi visnyk. 2020. No. 113. P. 92-97.

24. Siderates in modern agriculture / I. A. Shuvar et al. Ivano-Frankivsk : Symfoniia forte, $2015.156 \mathrm{p}$.

25. Slisarchuk M. Growing white mustard as an oilseed. Ahrobiznes Sohodni. URL: http://agrobusiness.com.ua/agro/ahronomiiasohodni/item/10623-vyroshchuvanniahirchytsi-biloi-iak-oliinoi-kultury.html (last accessed: 30.08.2021).

26. The state and prospects of growing oilseeds in Ukraine in the context of climate change / A. V. Mel'nik et al. Nauka i mir : 
выращивания масличных культур на Украине в условиях изменения климата / А. В. Мельник и др. Наука и мир : международный научный журнал. 2015. № 10. С. $113-116$.

27. Томашов С. В., Томашова О. Л. Оптимизация сроков сева и минерального питания горчицы белой в условиях Крыма. Известия государственного

Оренбургского аграрного университета. 2015. № 6 (56), ч. 1. С. 3840.

28. Урожайність гірчиці залежно від погодно-кліматичних умов ПівнічноСхідного Лісостепу України / С. В. Жердецька та ін. Вісник Сумського національного аграрного університету. 2016. № 2. C. 127-130.

29. Чехов А. В. Мировое производство семян масличных культур и пути их реализации. Наук.-техн. бюл. IОК УААН. 2001. Вип. 6. С. 1-4.

30. Шахід Алі. Вплив норм мінеральних добрив на ріст та розвиток рослин гірчиці білої в умовах ПівнічноСхідного Лісостепу України. Таврійський науковий вісник. 2018. № 101. С. 132-136.

31. Agustini R. Y. Effect on Growth and Yield of Mustard (Brassica juncea) to Addition of Coal Bottom Ash and Organic Matter. AGROSAINSTEK : Jurnal Ilmu dan Teknologi Pertanian. 2018. Vol. 2, No. 1. P. 40-43.

DOI: https://doi.org/10.33019/agrosainstek.v2i1.17.

32. The Effect of Different Rates of Nitrogen and Plant Density on Qualitative and Quantitative traits of Indian mustard / S. Keivanrad et al. Advances in Environmental Biology. 2012. No. 6. P. 145-152. mezhdunarodnyj nauchnyj zhurnal. 2015. No. 10. P. $113-116$.

27. Tomashov S. V., Tomashova O. L. Optimization of the sowing time and mineral nutrition of white mustard in the conditions of the Crimea. Izvestija Orenburgskogo gosudarstvennogo agrarnogo universiteta. 2015. No. 6 (56), part 1. P. 38-40.

28. Mustard yield depending on the weather and climatic conditions of the northeastern forest-steppe of Ukraine / S. V. Zherdetska et al. Visnyk Sumskoho natsionalnoho ahrarnoho universytetu. 2016. No. 2. P. 127-130.

29. Chehov A. V. World production of oilseeds and ways of their implementation. Nauk.-tekhn. biul. IOK UAAN. 2001. Issue 6. P. 1-4.

30. Shakhid Ali. Influence of the norms of mineral fertilizers on the growth and development of white mustard plants in the northeastern forest-steppe of Ukraine. Tavriiskyi naukovyi visnyk. 2018. No. 101. P. 132-136.

31. Agustini R. Y. Effect on Growth and Yield of Mustard (Brassica juncea) to Addition of Coal Bottom Ash and Organic Matter. AGROSAINSTEK : Jurnal Ilmu dan Teknologi Pertanian. 2018. Vol. 2, No. 1. P. 40-43.

DOI: https://doi.org/10.33019/agrosainstek.v2i1.17.

32. The Effect of Different Rates of Nitrogen and Plant Density on Qualitative and Quantitative traits of Indian mustard / S. Keivanrad et al. Advances in Environmental Biology. 2012. No. 6. P. 145-152.

Received 13.09.2021 